Goldschmidt 2021 Abstract

https://doi.org/10.7185/gold2021.8041

\section{The timescale and carbon flux recorded by skarn andradite from Gangdese arc, southern Tibet}

\section{ZHENHAO ZHOU, XU CHU AND JUNXING CHEN}

University of Toronto

Presenting Author: zhh.zhou@mail.utoronto.ca

Fluid-driven metamorphism in carbonate sequence gives rise to carbon release, of which the timescale is documented by the calc-silicate assemblages. In this study, we use andraditegrossular garnet to infer the timing and mass fluxes of decarbonation reactions in response to a 64 Ma granitoid emplacement in the Gangdese arc.

A garnet grain from the contact aureole shows distinctive dissolution-reprecipitation patterns. The host andradite crystal is crosscut by veins of porous garnet. These veins have lower $\mathrm{TiO}_{2}$, lower $\mathrm{MnO}$, and higher grossular components than the host andradite (Fig. 1). The host andradite includes abundant diopside, wollastonite and calcite, so we estimate a minimum temperature of $600{ }^{\circ} \mathrm{C}$ based on the phase relation at $2 \mathrm{kbar}$. We apply diffusion modeling to the sharp vein-host interface. For the $\mathrm{Mg}$ profiles, the best-fit $\operatorname{sqr}(D t)$ varies between 3.2 and $7.7 \times 10^{-}$ ${ }^{7} \mathrm{~m}$ ( $D$-diffusion coefficient, $t$-time), with the spatial averaging by electron microprobe accounted. If we assume the same diffusion kinetics as almandine garnet, applying the diffusion model of $\mathrm{Mg}$ [1] yields 2-12 kyr at $600{ }^{\circ} \mathrm{C}$ (Fig. 2). This short timescale might still be significantly overestimated because the large unit-cell dimension and high water content of garnet accelerate diffusion by orders of magnitude. Notably, the fitted $\operatorname{sqrt}(D t)$ of $\mathrm{Al} /\left(\mathrm{Al}+\mathrm{Fe}^{3+}\right)$ and Ti profiles are close to that of $\mathrm{Mg}$, so the diffusion coefficients of $\mathrm{Al}-\mathrm{Fe}^{3+}$ and $\mathrm{Ti}$ appear comparable to $\mathrm{Mg}$. The diffusion of $\mathrm{Ti}$ and $\mathrm{Al}-\mathrm{Fe}^{3+}$ in andradite-grossular garnet could be potential geospeedometers applicable to skarn deposits. Given the millennial duration, mass balance calculations applied to various lithologic units in this aureole yield a carbon flux of $\sim 75 \mathrm{~mol} \mathrm{year}^{-1} \mathrm{~m}^{-2}$ for a $150 \mathrm{~m}$ reaction front. The areal carbon release scales to a carbon flux of $\sim 2$ Tmol/year of the whole Gangdese batholith. The vast carbon flux is of the same magnitude as the late Cretaceous global carbon flux contributed by contact metamorphism [2].

[1] Chu \& Ague (2015), Contributions to Mineralogy and Petrology 170.

[2] Chu, Lee, Dasgupta \& Cao (2019), American Journal of Science 319, 631-657.
Fig. 1
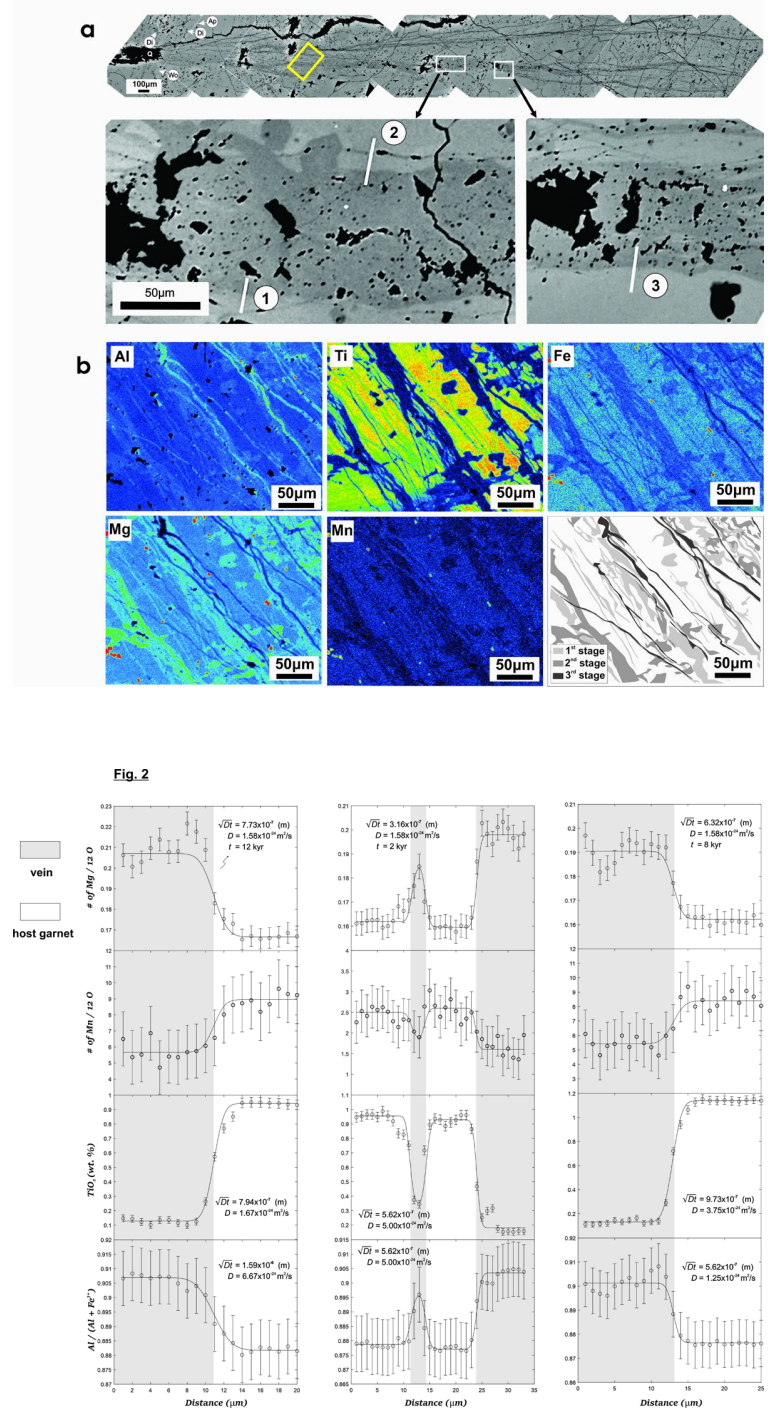